\title{
Application of Factorial Design for the Optimization of Hexavalent Chromium Removal Using a New Low-cost Adsorbent: Adsorption Isotherms, Thermodynamic and Kinetic Studies
}

\author{
Aziz El Kassimi 1,*D, Youness Achour 1, Imane nadir 1, Mamoune El Himri 1, My Rachid \\ Laamari ${ }^{1}$, Mohammadine El Haddad 1,* (D) \\ 1 Laboratory of Analytical and Molecular Chemistry, Poly-disciplinary Faculty of safi, Cadi Ayyad University, BP 4162, \\ 46000 Safi, Morocco \\ * Correspondence: azizelkassimi2012@gmail.com (A.E.K.); elhaddad71@gmail.com (M.E.H.); \\ Scopus Author ID 57191952633
}

Received: 8.03.2021; Revised: 8.04.2021; Accepted: 12.04.2021; Published: 26.04.2021

\begin{abstract}
This research work involved using factorial experimental design techniques to investigate the adsorption of hexavalent chromium from an aqueous solution on medlar activated carbon. A $2^{4}$ full factorial experimental design was employed to determine the optimum values and degree of importance of parameters: $\mathrm{pH}$, initial $\mathrm{Cr}$ (VI) concentration, adsorbent dose, and contact time at two levels. The optimized conditions for hexavalent chromium $\mathrm{Cr}(\mathrm{VI})$ removal were at initial pH 1.5, $5 \mathrm{mg} . \mathrm{L}^{-1} \mathrm{Cr}(\mathrm{VI})$, adsorbent dose $6 \mathrm{mg}$, and $60 \mathrm{~min}$ adsorption time. The results predicted a good agreement between the predicted values $\left(R^{2}=0.9909\right)$, as obtained by the model, and the experimental value $\left(R^{2}=0.9977\right)$. The main effects and interaction effects were analyzed using analysis of variance (ANOVA), F-test and Pvalues to define the most important process variables affecting $\mathrm{Cr}$ (VI) adsorption. The most significant variables were therefore the $\mathrm{pH}$ of the solution and the adsorbent dose. Therefore, the present results demonstrate that medlar activated carbon should be regarded as a low-cost alternative for removing $\mathrm{Cr}$ (VI) from an aqueous solution. The adsorption data were evaluated by Langmuir, Freundlich, and Dubinin-Radushkevich isotherms. The results showed that the Langmuir isotherm model best describes the equilibrium adsorption with a high correlation coefficient.
\end{abstract}

Keywords: adsorptive removal; $\mathrm{Cr}(\mathrm{VI})$; medlar activated carbon; experimental design; kinetics; thermodynamics.

(C) 2021 by the authors. This article is an open-access article distributed under the terms and conditions of the Creative Commons Attribution (CC BY) license (https://creativecommons.org/licenses/by/4.0/).

\section{Introduction}

Pollution by heavy metals is considered a serious threat to the environment and especially to human health. Rapid industrialization has led to an increase in the removal of heavy metals from the environment. Hence, effluent treatment is one of the most important industry tasks due to their toxic nature and accumulation through the food chain as nonbiodegradable pollutants. The most familiar heavy metals pollutants are chromium, lead, cadmium, copper, and mercury. Among them, chromium, one of the top-priority toxic heavy metals in wastewater, has been widely used in various industrial processes, such as petroleum refining, battery, metallurgy, electroplating, tanning, textile, and manufacturing of dye and metal corrosion inhibition [1-3]. Chromium exists in two stable oxidation states, trivalent chromium $\mathrm{Cr}$ (III) and hexavalent chromium $\mathrm{Cr}$ (VI) forms. 
The hexavalent $\mathrm{Cr}$ (VI) is generally considered more toxic than the trivalent $\mathrm{Cr}$ (III) form because it is very soluble and can be easily absorbed and accumulated in the body, especially in kidneys, liver and even cause lung cancer [4, 5]. For this reason, Cr (VI) is considered a priority hazardous pollutant. According to the World Health Organization (WHO) recommendation for drinking water recommendations, the maximum allowable level for total chromium is $0.05 \mathrm{mg} / \mathrm{L}[6]$.

Various traditional methods are applied for the removal of environmental pollution. Especially, the contamination of water by toxic heavy metal ions is a global environmental problem. Adsorption is an alternative method suitable for the treatment of wastewater. Its comparative advantage over other treatment techniques includes the availability of adsorbent, low treatment cost, high efficiency, and simplicity to operate for removing trace-levels metal ions from aqueous systems. Numerous studies reported the removal of $\mathrm{Cr}$ (VI) using different adsorbents such as activated carbon [7-9], sugar cane pulp residue [10], waste tires [11], and rice husk ash [12]. Activated carbons, because of their high surface area, microporous character, and the chemical nature of their surface, have been considered potential adsorbents to remove heavy metals from industrial effluents [13].

The application of statistical experimental design techniques in adsorption process development can improve product yields and reduce process variability, development time, and overall costs $[14,15]$. In this context, the main objective of this work was to optimize the adsorption of $\mathrm{Cr}$ (VI) from aqueous solution onto medlar activated carbon using full factorial design (FFD) and determine the adsorption kinetics isotherms and thermodynamics studies.

\section{Materials and Methods}

\subsection{Preparation of medlar activated carbon.}

The medlar was collected from the region of Safi in Morocco and washed with distilled water for removing dirt and other foreign particles. After the drying process, Chemical activation of the medlar precursor was done with $\mathrm{H}_{3} \mathrm{PO}_{4}(2.5 \mathrm{M})$ mixed with distilled water and completed by carbonization at temperature $500^{\circ} \mathrm{C}$ for 3 hours producing a medlar activated carbon. The medlar activated carbon product was repeatedly rinsed several times with distilled water until clearness and neutral $\mathrm{pH}$ and then dried at $105^{\circ} \mathrm{C}$ for about $12 \mathrm{~h}$. The activated carbon is abbreviated as "MAC" throughout the manuscript.

\subsection{Characterization of medlar activated carbon.}

Fourier Transform Infra-Red spectroscopy (FTIR) and scanning electron microscope (SEM) analysis were applied in order to identify the presence of functional groups and to characterize the surface morphology of MAC adsorbent by using FTIR spectroscope (Perkin Elmer model) and with HITACHI-S4100 equipment operated at $20 \mathrm{kV}$, respectively.

\subsection{Batch adsorption experiments.}

A stock solution of $\mathrm{Cr}(\mathrm{VI})$ was prepared $(1000 \mathrm{mg} / \mathrm{L})$ by dissolving $2.828 \mathrm{~g}$ of potassium dichromate $\left(\mathrm{K}_{2} \mathrm{Cr}_{2} \mathrm{O}_{7}\right)$ in double-distilled water and diluting to obtain desired concentration ranging from 1 to $6 \mathrm{mg} / \mathrm{L}$. All the other chemicals used in the study were of analytical grade. The initial $\mathrm{pH}$ was adjusted with the addition of $0.1 \mathrm{~mol} \mathrm{~L}^{-1}$ solutions of $\mathrm{NaOH}$ or $\mathrm{HCl}$ to the desired values using a pH-Meter HANNA 5222. 
Batch experiments based on the full factorial design (FFD) were conducted at random to study the effect of the pre-selected four operating variables on the $\mathrm{Cr}$ (VI) removal efficiency of the medlar activated carbon (MAC). For adsorption efficiency optimization, the experiments were conducted at different $\mathrm{pH}(1.5$ - 9), initial $\mathrm{Cr}$ (VI) concentration (1-5 mg/L), and adsorbent dose $(1-6 \mathrm{mg}$ ) with contact time varying from $30-60 \mathrm{~min}$ at a constant agitation speed of $600 \mathrm{rpm}$. Total hexavalent chromium concentration was measured by a spectrophotometer (Jenway 6300). The pink complex formed from 1.5-diphenyl carbazide prepared in acetone and $\mathrm{Cr}$ (VI) in acidic solution was analyzed at $540 \mathrm{~nm}$ [16].

The percentage removal (\%) and amount of adsorption at equilibrium qe (mg/g) of $\mathrm{Cr}$ (VI) were calculated using the equations (1) and (2), respectively:

$\%$ Removal dye $=\frac{C_{0}-C_{e}}{C_{0}} * 100$

$q_{e}(m g / g)=\frac{C_{0}-C_{e}}{W} * V$

\subsection{Statistical analysis.}

The experimental design is an essential tool for studying the individual and interaction effects of all parameters simultaneously [16, 17]. A factorial design is applicable for optimization of the main effects of variables, and their interactions are compared with one another in order to estimate the influence of the different variables and employed to reduce the total number of experiments to achieve the best overall optimization of the process [18-21]. A common experimental design is one with all input factors set at two levels each. These levels are called 'high $(+1)$ ' and 'low $(-1)$ ', respectively. If there are k factors each at two levels, a full factorial design has $2^{\mathrm{k}}$ runs.

\section{Results and Discussion}

\subsection{Characterization of MAC adsorbent.}

The FTIR spectrum obtained for the medlar activated carbon as shown in Figure 1(a), the band located between 3200 and $3600 \mathrm{~cm}^{-1}$ was attributed to the amine $(\mathrm{N}-\mathrm{H})$ and hydroxyl groups (O-H) (phenols, carboxyl, or alcohols) [22]. The bands at 2929 and $2852 \mathrm{~cm}^{-1}$ are arising from aliphatic $\mathrm{C} \mathrm{H}$ stretching. The peak appearing on the spectrum range of 1400-1600 $\mathrm{cm}^{-1}$ is typically attributed to vibrations of the $\mathrm{C}=\mathrm{C}$ bonds in the aromatic rings or the groups $\mathrm{C}-\mathrm{O}$ of alcool or ether or hydroxyl group [23, 24]. These functional groups were attributed to the existence of cellulose and hemicelluloses bending in the structure of medlar activated carbon, which made the Cr (VI) removal feasible. The SEM micrograph was prepared and is presented in Figure 1(b). It can be seen from the micrographs that the surface of medlar activated carbon has a highly porous structure with greater heterogeneity.

\subsection{Design of experiments by FFD.}

In this study, a full factorial design experiment was employed to analyze adsorption of hexavalent chromium Cr (VI). Table 1 illustrates the 4 factors used including, $\mathrm{pH}$ (A), initial $\mathrm{Cr}$ (VI) concentration (B), adsorbent dose (C), and contact time (D). By using $2^{4}$ full factorial designs, a total of 16 experimental runs were performed. Input factor levels were -1 (low level) and +1 (high level), which indicates the lowest range of factors and the highest range of factors, 
respectively. The results were analyzed using the software Design Expert 11. The main effects and interactions effects of varied factors were determined.

(a)

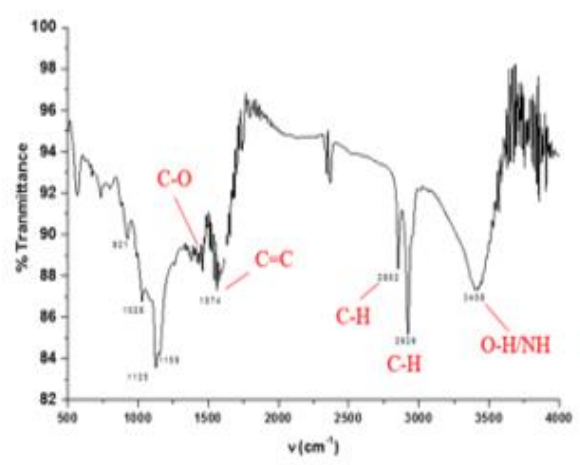

(b)

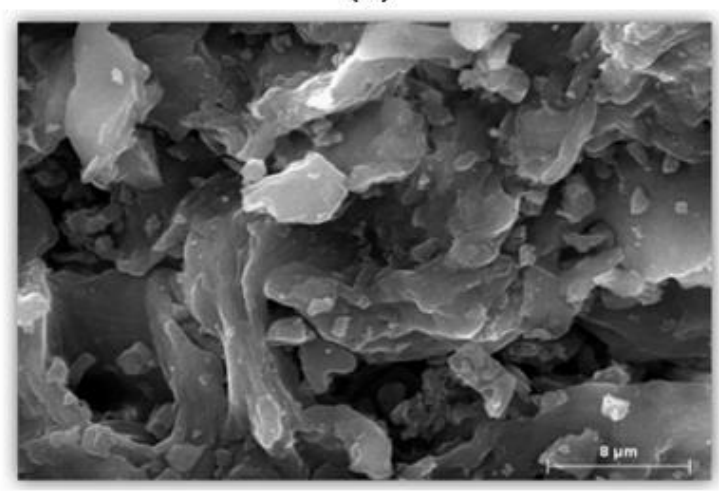

Figure 1. (a) FT-IR spectra and (b) SEM images of medlar activated carbon adsorbent.

Table 1. Experimental ranges and levels of the factors used in the factorial design.

\begin{tabular}{l|c|c|c}
\multirow{2}{*}{ Independent variable } & Coded symbol & \multicolumn{2}{|c}{ Range and level } \\
\cline { 3 - 4 } & & $\mathbf{- 1}$ & $\mathbf{+ 1}$ \\
\hline $\mathrm{pH}$ & $\mathrm{A}$ & 1.5 & 9 \\
\hline Concentration $(\mathrm{mg} / \mathrm{L})$ & $\mathrm{B}$ & 1 & 6 \\
\hline Adsorbent dose $(\mathrm{mg})$ & $\mathrm{C}$ & 1 & 60
\end{tabular}

The general form of the codified equation with four factors model is as follows:

$\mathrm{R}(\%)=\mathrm{X}_{0}+\mathrm{X} 1 \mathrm{~A}+\mathrm{X} 2 \mathrm{~B}+\mathrm{X} 3 \mathrm{C}+\mathrm{X} 4 \mathrm{D}+\mathrm{X} 5 \mathrm{AB}+\mathrm{X} 6 \mathrm{AC}+\mathrm{X} 7 \mathrm{AD}+\mathrm{X} 8 \mathrm{BC}+\mathrm{X} 9 \mathrm{BD}+$ $\mathrm{X} 10 \mathrm{CD}+\mathrm{X} 11 \mathrm{ABC}+\mathrm{X} 12 \mathrm{ABD}+\mathrm{X} 13 \mathrm{ACD}+\mathrm{X} 14 \mathrm{BCD}+\mathrm{X} 15 \mathrm{ABCD}$ (3)

Where $\mathrm{R}(\%)$ is the percentage removal of $\mathrm{Cr}(\mathrm{VI}), \mathrm{X}_{0}$ is the global mean, $\mathrm{Xi}$ represents the other regression coefficients, and $\mathrm{A}, \mathrm{B}, \mathrm{C}$, and $\mathrm{D}$ stands for $\mathrm{pH}$, initial concentration of $\mathrm{Cr}(\mathrm{VI})$, amount of adsorbent and contact time, respectively. By substituting the coefficients $\mathrm{X}_{0}$ and $\mathrm{xi}$ in Eq. (3) by their values, we get:

$\mathrm{Cr}(\mathrm{VI})$ removal $(\%)=54.42-12.82 \mathrm{~A}-0.14 \mathrm{~B}+12.08 \mathrm{C}+2.50 \mathrm{D}+1.77 \mathrm{AB}+0.78 \mathrm{AC}-$ $1.00 \mathrm{AD}+0.25 \mathrm{BC}-0.46 \mathrm{BD}-0.50 \mathrm{CD}-6.95 \mathrm{ABC}+0.23 \mathrm{ABD}+0.21 \mathrm{ACD}+0.01 \mathrm{BCD}+$ $0.03 \mathrm{ABCD}$

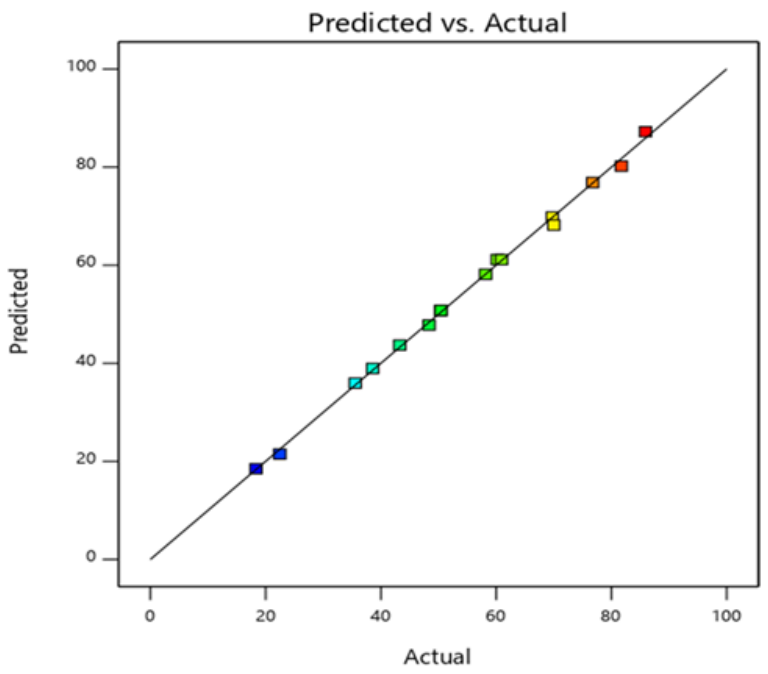

Figure 2. The actual and predicted response plot of $\mathrm{Cr}(\mathrm{VI})$ removal (\%) onto MAC adsorbent. 
The positive sign in front of the terms indicates a synergistic effect, while the negative sign indicates an antagonistic effect [16]. The removal efficiencies (\%) of $\mathrm{Cr}$ (VI) have been predicted by Figure 2 and are presented in Table 2. In general, there were agreements between the experimental and predicted values of $\mathrm{Cr}(\mathrm{VI})$ removal efficiency.

Table 2. Factorial design matrix of four variables along with experimental and predicted responses for Cr (VI) removal by MAC.

\begin{tabular}{l|c|c|c|c|c|c|c} 
Run No & \multicolumn{4}{|c}{ Coded values of independent variables } & \multicolumn{3}{c}{ Cr (VI) removal (\%) } \\
\hline & A & B & C & D & Observed & Predicted & Residual \\
\hline 1 & -1 & -1 & -1 & -1 & 60.18 & 61.17 & -0.991 \\
\hline 2 & +1 & -1 & -1 & -1 & 18.34 & 18.50 & -0.162 \\
\hline 3 & -1 & +1 & -1 & -1 & 43.27 & 43.71 & -0.438 \\
\hline 4 & +1 & +1 & -1 & -1 & 35.54 & 35.97 & -0.425 \\
\hline 5 & -1 & -1 & +1 & -1 & 69.74 & 69.84 & -0.100 \\
\hline 6 & +1 & -1 & +1 & -1 & 58.17 & 58.16 & 0.008 \\
\hline 7 & -1 & +1 & +1 & -1 & 81.74 & 80.21 & 1.530 \\
\hline 8 & +1 & +1 & +1 & -1 & 48.37 & 47.79 & 0.578 \\
\hline 9 & -1 & -1 & -1 & +1 & 70.00 & 68.20 & 1.800 \\
\hline 10 & +1 & -1 & -1 & +1 & 22.47 & 21.50 & 0.975 \\
\hline 11 & -1 & +1 & -1 & +1 & 50.36 & 50.73 & -0.373 \\
\hline 12 & +1 & +1 & -1 & +1 & 38.57 & 38.96 & -0.387 \\
\hline 13 & -1 & -1 & +1 & +1 & 76.75 & 76.86 & -0.115 \\
\hline 14 & +1 & -1 & +1 & +1 & 60.93 & 61.15 & -0.223 \\
\hline 15 & -1 & +1 & +1 & +1 & 85.92 & 87.23 & -0.310 \\
\hline 16 & +1 & +1 & +1 & +1 & 50.42 & 50.78 & -0.363
\end{tabular}

3.2.1. Analysis of variance (ANOVA).

The quality of the model was validated using the analysis of variance method (ANOVA). The sum of squares (SS) and mean square (MS) of each factored P-value and Pvalue were determined by choosing an $\alpha$ risk of $5 \%$. P-value is the probability value that is used to determine the statistically significant effects in the model [25-27].

The variance analysis for Cr (VI) removal by the FFD model is tabulated in Table 3. The main effects and interaction effects of each factor having a P-value $<0.05$ are considered as potentially significant, and a value that $>0.1$ indicates the model term is not significant. The values of "Probability $>F$ " less than 0.05 indicated that model terms viz. A, C, D, AB, AC, AD, and $\mathrm{ABC}$ were significant. The regression analysis produced the following equation with $\mathrm{R} 2$ of 0.9982 and $\mathrm{p}<0.0001$ to remove $\mathrm{Cr}$ (VI).

After discarding insignificant terms, the resultant models can be represented as:

$\mathrm{Cr}(\mathrm{VI})$ removal $(\%)=54.42-12.82 \mathrm{~A}+12.08 \mathrm{C}+2.50 \mathrm{D}+1.77 \mathrm{AB}+0.78 \mathrm{AC}-1.01 \mathrm{AD}-$ 6.96ABC

Table 3. Estimated regression coefficients of significant factors and their effects for $\mathrm{Cr}$ (VI) removal.

\begin{tabular}{l|c|c|c|c|c|c} 
Source & $\begin{array}{c}\text { Degrees of } \\
\text { freedom }\end{array}$ & $\begin{array}{c}\text { Sum of } \\
\text { Squares }\end{array}$ & $\begin{array}{c}\text { Mean } \\
\text { Square }\end{array}$ & F-value & P-value & Prob > F \\
\hline Model & 7 & 5917.49 & 845.36 & 644.89 & $<0.0001$ & significant \\
\hline A-pH & 1 & 2630.41 & 2630.41 & 2006.63 & $<0.0001$ & \\
\hline C- Adsorbent dose & 1 & 2335.55 & 2335.55 & 1781.70 & $<0.0001$ & \\
\hline D-Contact time & 1 & 100.35 & 100.35 & 76.55 & $<0.0001$ & \\
\hline AB & 1 & 50.30 & 50.30 & 38.37 & 0.0003 & \\
\hline AC & 1 & 9.97 & 9.97 & 7.61 & 0.0248 & \\
\hline AD & 1 & 16.26 & 16.26 & 12.40 & 0.0078 & \\
\hline ABC & 1 & 774.65 & 774.65 & 590.95 & $<0.0001$ & \\
\hline Residual & 8 & 10.49 & 1.31 & & & \\
\hline Cor Total & 15 & 5927.97 & & & &
\end{tabular}

Notes: mean 54.42, C.V. \% 2.10, Std. Dev. 1.14, R2 0.9982, AdjR2 0.9967, PredR2 0.9929, Adeq precision (AP) 84.898 . 
The linear correlation $\left(\mathrm{R}^{2}\right)$, which was used to evaluate the correlation between the actual and predicted responses, was obtained from the developed model to be 0.9967 [28]. This demonstrates that $99.67 \%$ of the variation for percentage removal of $\mathrm{Cr}$ (VI) is described by the variables studied and indicated only $0.33 \%$. On the other hand, the coefficient of variation (CV) is not greater than $10 \%$, so the model can be considered reasonable as the $\mathrm{CV}$ is the ratio of the standard error of estimate to the mean value of the observed response [29]. The CV also is a measure of the reproducibility of the model [30]. So, the observed $2.10 \%$ indicated high precision and reliability of the experimental design. The "Predicted $\mathrm{R}^{2}$ " of 0.9929 was found to be in reasonable agreement with "Adjusted $\mathrm{R}^{2}$ " of 0.9967 . It was also noticed that the Adequate Precision (AP) measured the signal-to-noise ratio. A ratio greater than 4 was desirable. The adequate precision (AP) of 84.898 indicates adequate model discrimination [31] demonstrates the process's significance.

\subsubsection{Main and interaction effects.}

The main effects of each parameter on the Cr (VI) removal efficiency (\%) is shown in Figure. 3. The main effects represent variations of the average between the high and low levels for each factor. The sign of the main effect indicates the directions of the effect. It can be seen from Figure 3. The effect of $\mathrm{pH}(\mathrm{A})$ was characterized by a greater degree of departure and also had a negative effect on the response, whereas the adsorbent dose (C) of MAC has a negative effect on the response with greater departure.

The interaction effect is effective when the change in the response from low to high levels of a factor is dependent on the level of a second factor, as shown in Figure 4. If the lines of two factors are superimposed and parallel, indicating that the factors' effect is not significant. In contrast, when the lines are not parallel, the two factors interact together. From Figure 4 the interaction between $\mathrm{AB}, \mathrm{AC}, \mathrm{AD}$, and $\mathrm{ABC}$ is significant; in contrast, $\mathrm{BC}, \mathrm{BD}, \mathrm{DC}$ is not significant.

To better understand the relationship between factors and a response, a cube plot was carried out (Figure 5). The cube plot indicates that decreasing $\mathrm{pH}$ from 9 to 1.5 enhances the $\mathrm{Cr}$ (VI) removal efficiency significantly by $34.44 \%$ (from 49.28 to $83.72 \%$ ) at higher concentration $(5 \mathrm{mg} / \mathrm{L})$, while at low concentration $(1 \mathrm{mg} / \mathrm{L})$, changes in $\mathrm{pH}$ do not have a greater effect (a decrease of only $9.76 \%$ ).

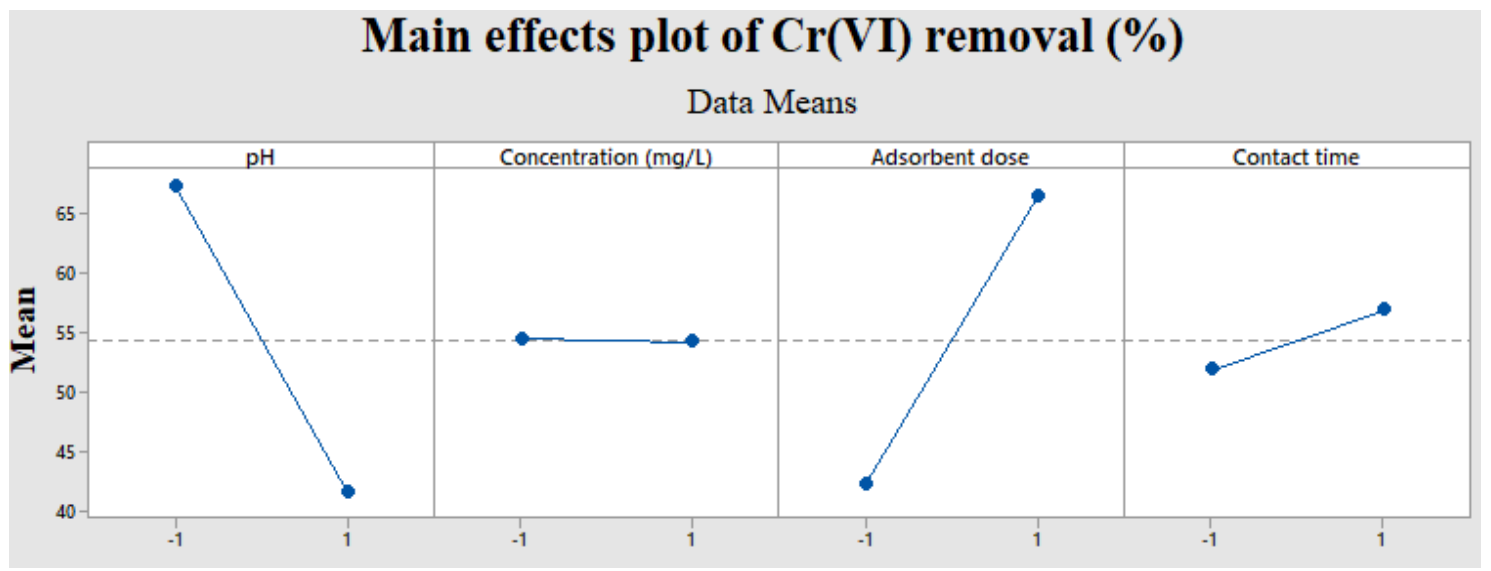

Figure 3. Main effect plots of $\mathrm{Cr}(\mathrm{VI})$ removal (\%) onto MAC adsorbent. 


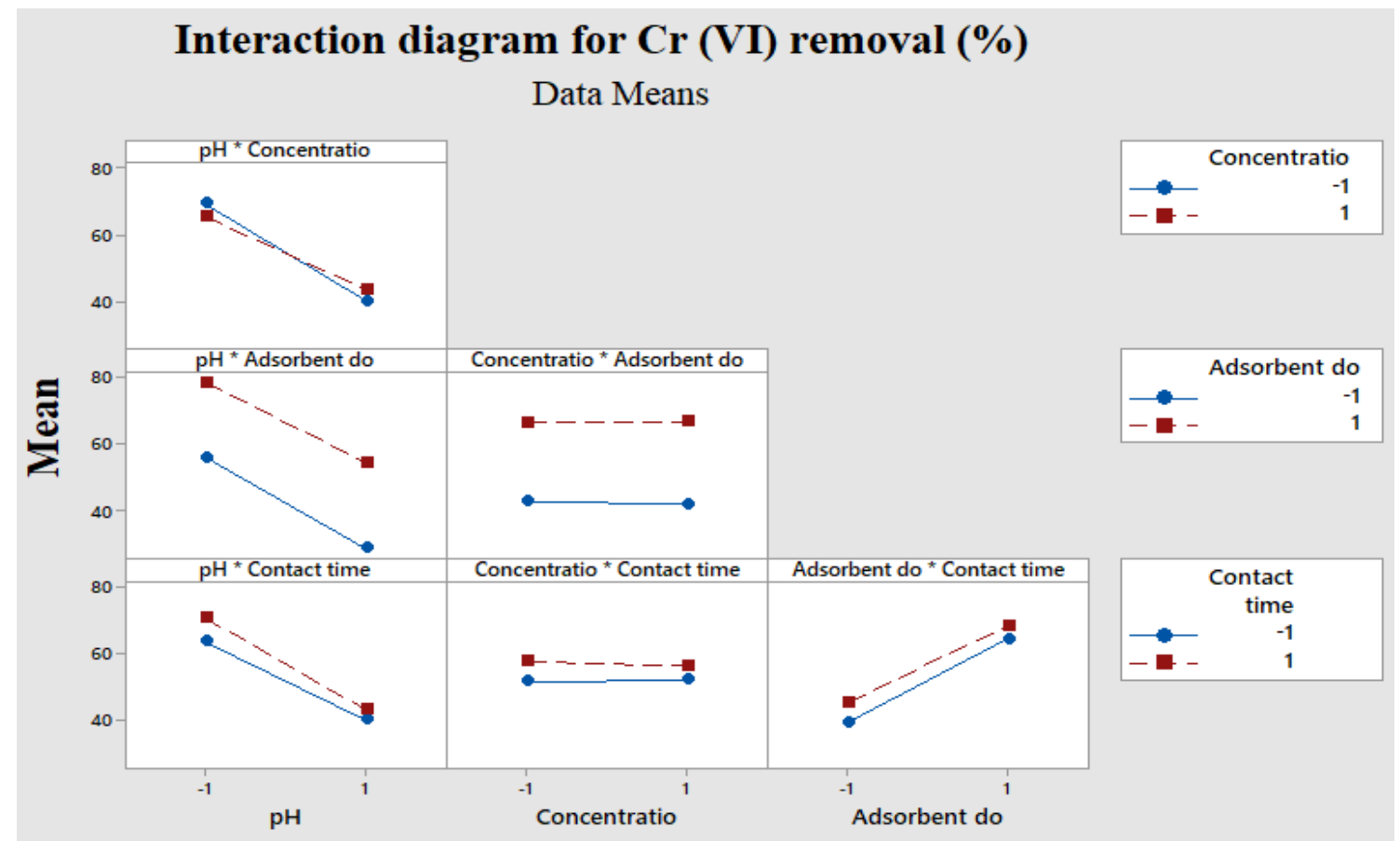

Figure 4. Interaction effects plots for $\mathrm{Cr}(\mathrm{VI})$ removal (\%) onto MAC adsorbent.

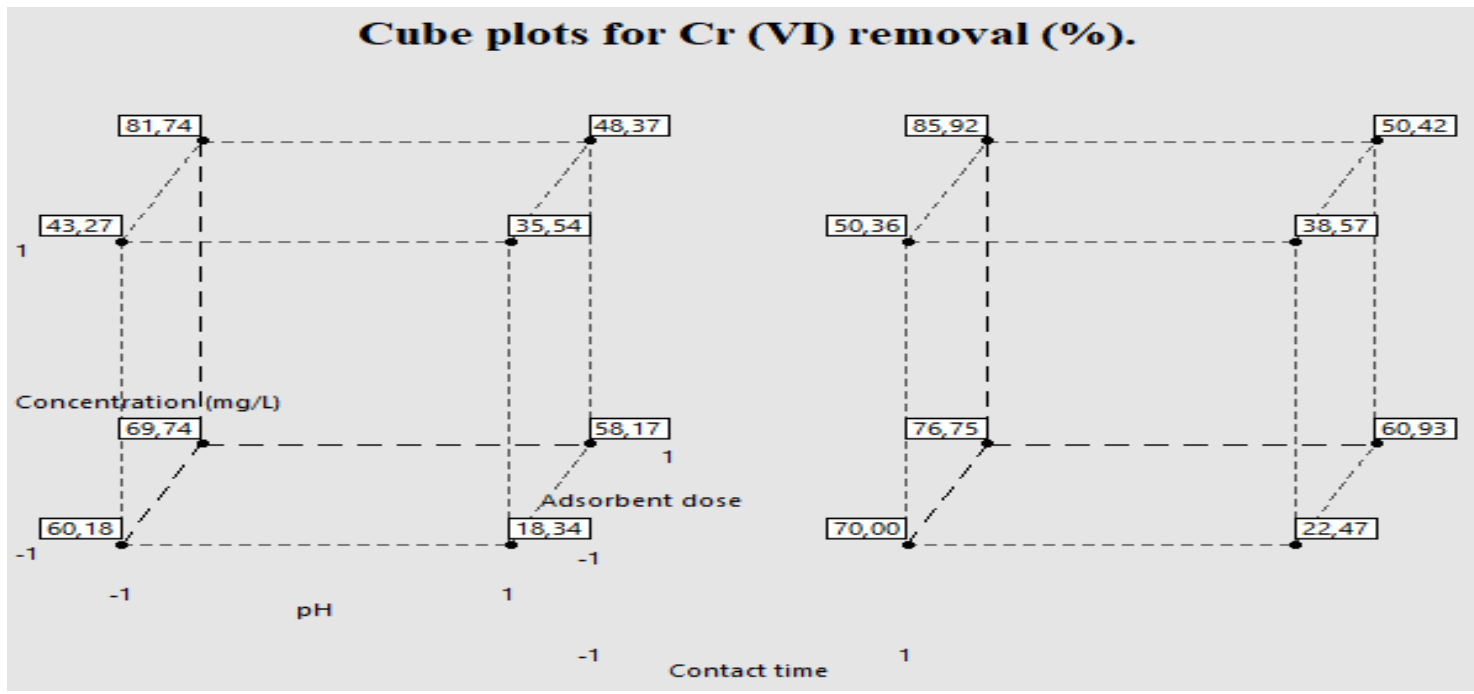

Figure 5. Cube plots for $\mathrm{Cr}(\mathrm{VI})$ removal (\%).

\subsubsection{D surfaces, contour and perturbation plots.}

To assess the effects of variables, the 3D surfaces, 2D contour, and perturbation plots are demonstrated for a function of two factors. This representation shows the relative effects of any two variables when the remaining variables are kept constant in analyzing Figure. 6A, we see that the adsorption performance increases from 49.28 to $83.72 \%$ when the $\mathrm{pH}$ decreases and the initial concentration of the adsorbate increases. Figure $6 \mathrm{~B}$ shows that the $\mathrm{Cr}$ (VI) removal efficiency (\%) increased with decreasing $\mathrm{pH}$ from 9 to 1.5 and increasing the adsorbent dose from $1 \mathrm{mg}$ to $6 \mathrm{mg}$. Cr (VI) maximal removal efficiency is observed at $5 \mathrm{mg} / \mathrm{L}$ and 60 min for concentration and contact time, respectively. Finally, the effect of interaction between $\mathrm{pH}$ and contact time is shown in Figure 6C. The plot revealed that the percentage of $\mathrm{Cr}$ (VI) removal increased with a decrease in $\mathrm{pH}$ and increase contact time.

Contour plots for the significant interactions were shown in Figure 6(A) (B) and (C). The interaction plots showed that interaction of $\mathrm{pH}$ and $\mathrm{Cr}(\mathrm{VI})$ concentration played a major 
role. These two factors also interacted strongly with other factors indicating predominant influence in removal. Interactions of $\mathrm{pH}$ and $\mathrm{Cr}(\mathrm{VI})$ concentration with adsorbent dose were significant on the response. This is probably because better mass transfer occurred from aqueous medium to solid adsorbent [32]. Almost similar results were reported in the earlier work [33-35].
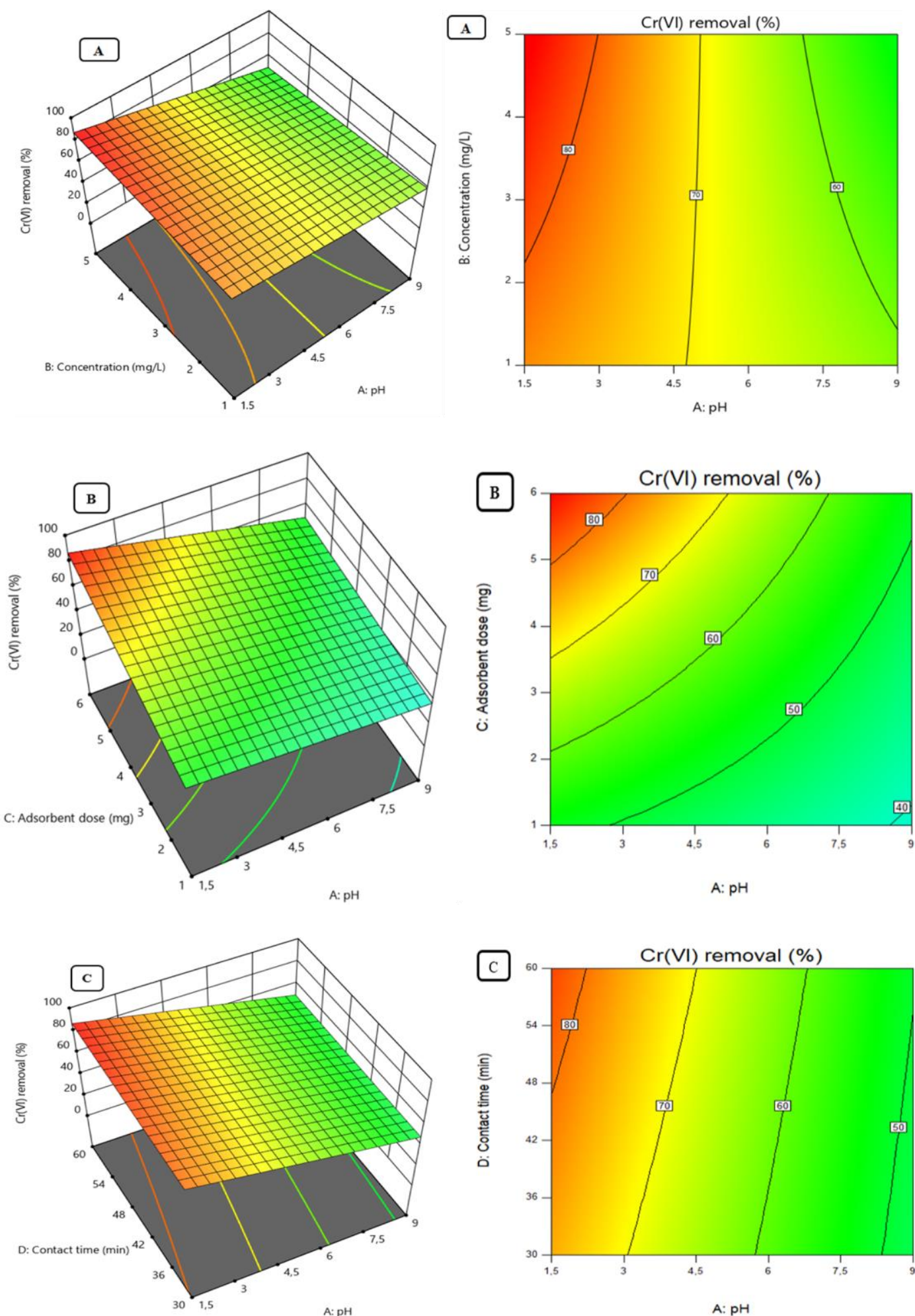

Figure 6. Response surface plots and contour of the interaction effect of two independent variables: (A) $\mathrm{pH}$ and $\mathrm{C}(\mathrm{VI})$ concentration, (B) $\mathrm{pH}$ and adsorbent dose, (C) $\mathrm{Cr}(\mathrm{VI})$ concentration and contact time on $\mathrm{Cr}(\mathrm{VI})$ removal $(\%)$. 
Another convenient effect of variables on responses is the use of perturbation plots. The perturbation plot (Figure 7) of the four independent factors in response surface models shows how the response changes as each factor change from the chosen reference point, while the other factors are held constant at a reference value. In this case, at the center point, factor A $(\mathrm{pH})$ and $\mathrm{C}$ (adsorbent dose) provide a relatively high effect on $\mathrm{Cr}(\mathrm{VI})$ percentage removal as it changes from the reference point. The higher amount of adsorbent dose and $\mathrm{pH}$ lead to higher removal (\%) of $\mathrm{Cr}(\mathrm{VI})$. Factors $\mathrm{B}$ and $\mathrm{D}$ have the same effect as factors $\mathrm{A}$ and $\mathrm{C}$, but it can be concluded that term B and D has less effect than term A and C.

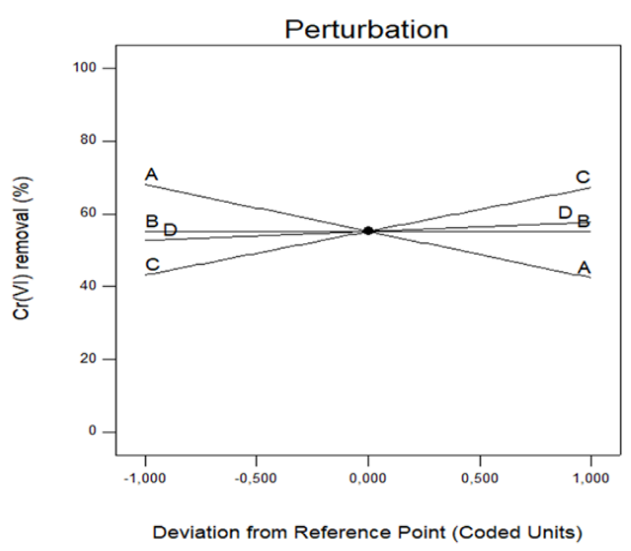

Figure 7. Perturbation plot of factors (A) $\mathrm{pH},(\mathrm{B}) \mathrm{Cr}(\mathrm{VI})$ concentration, (C) adsorbent dose and (D) contact time.

\subsubsection{Normal probability plot.}

A normal probability plot is applied to judge the normality of data as "real" or "chance" [36-38]. The model's adequacy was evaluated using a diagnostic plot (normal \% probability versus studentized residuals and studentized residuals versus run number), which is presented in Figures 8a and 8b. In Figure 8a, the points are spread almost on a straight line along the diagonal for both cases. This trend shows that the error terms are normally dispersed and independent of each other. Also, it was observed in Figure $8 \mathrm{~b}$ that the points are randomly scattered surrounding zero on the studentized residuals axis in between +4.5 and -4.5 in both the cases, which indicates homoscedasticity and establishing the adequacy of the respective model.
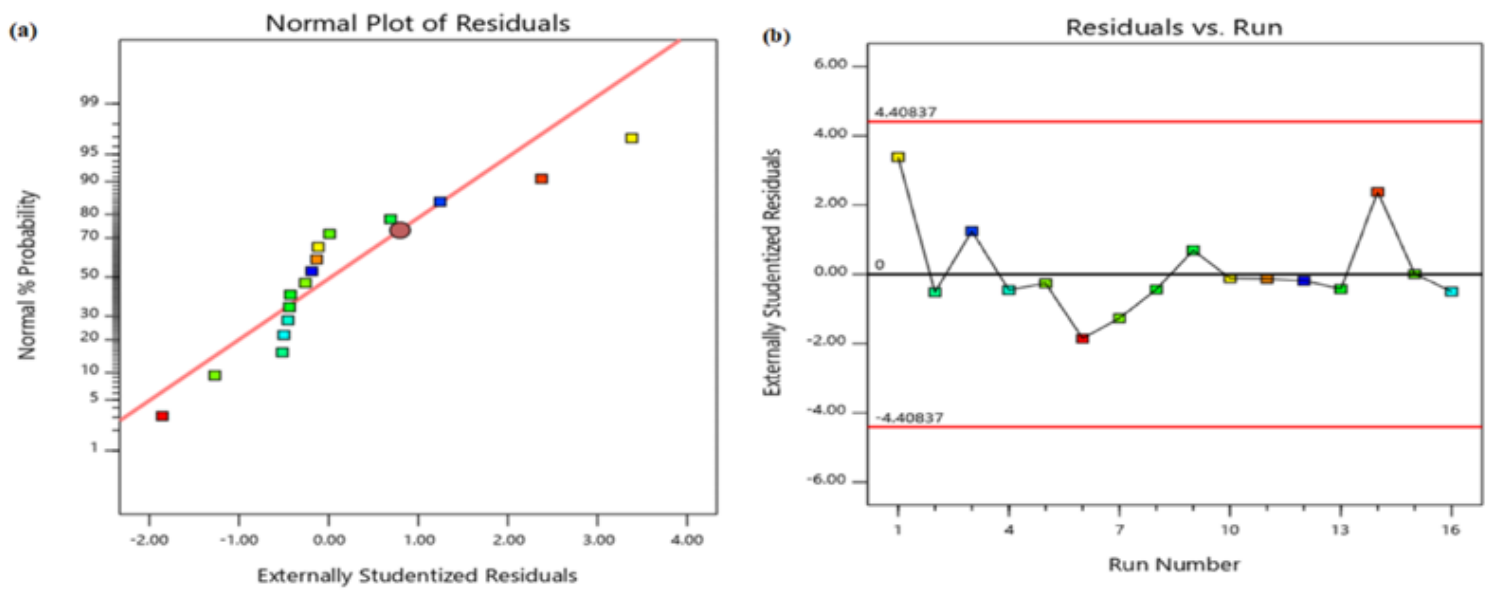

Figure 8. Diagnostic plot of the model for Cr (VI) (a) Normal (\%) probability versus studentized residuals (b) Studentized residuals versus the run number. 


\subsubsection{Optimization and validation of result.}

Maximum Cr (VI) removal efficiency was found to be $85.92 \%$. However, the present investigation was carried out to find the optimum process conditions through FFD for the highest desirability. The desirability of an experience with a value close to unity is considered the best condition. To obtain the optimal condition for $\mathrm{Cr}$ (VI) removal with adsorption process, $\mathrm{pH}$ at the minimum level, the initial concentration at the maximum level, adsorbent dosage at the maximum level, and contact time in a range were set for maximum desirability (Figure 9). After setting the above conditions, the optimum conditions were given by the statistical software [39]. The best local maximum removal was found to be at initial $\mathrm{pH}$ of $1.5, \mathrm{Cr}$ (VI) concentration of $5 \mathrm{mg} / \mathrm{L}$, the adsorbent dosage of $6 \mathrm{mg} / 50 \mathrm{~mL}$, and contact time $60 \mathrm{~min}$ with $\mathrm{Cr}$ (VI) removal of $85.91 \%$ and desirability of 0.991 (Figure 9).
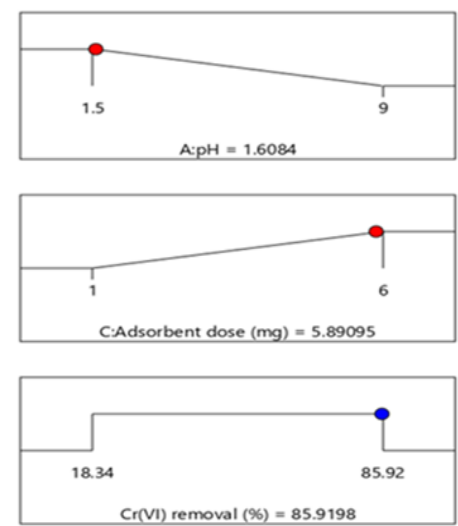

Figure 9. Ramp desirability for optimization of $\mathrm{Cr}$ (VI) adsorption.
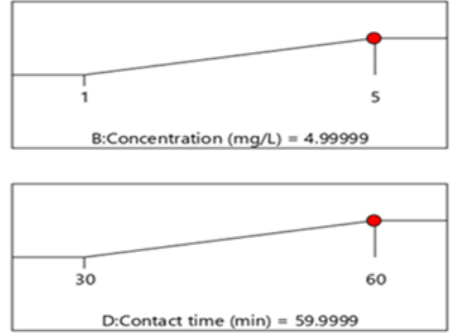

Desirability $=0.991$

\subsection{Adsorption kinetics.}

Adsorption kinetics were used to examine the adsorption mechanism such as chemical reaction, diffusion control, or mass transfer coefficient by the various models, namely pseudofirst-order, pseudo-second-order intraparticle diffusion model, respectively. The linearized forms of these models are represented below [40-42]:

First-order model $\quad \log \left(\mathrm{q}_{\mathrm{e}}-q_{t}\right)=\log \left(\mathrm{q}_{\mathrm{e}}\right)-\frac{\mathrm{k}_{1}}{2.303} t$

Second-order model

$$
\frac{\mathrm{t}}{\mathrm{q}_{\mathrm{t}}}=\frac{1}{\mathrm{k}_{2} \mathrm{q}_{\mathrm{e}}^{2}}+\frac{1}{\mathrm{q}_{\mathrm{e}}} \mathrm{t}
$$

Intraparticle diffusion mode $\quad \mathrm{q}_{\mathrm{t}}=\mathrm{k}_{\mathrm{id}} \mathrm{t}^{1 / 2}+\mathrm{C}_{\mathrm{i}}$

Where $\mathrm{q}_{\mathrm{e}}$ is the theoretically adsorbed amount at equilibrium $(\mathrm{mg} / \mathrm{g}), \mathrm{q}_{\mathrm{t}}$ is the amount adsorbed at any time $(\mathrm{t})(\mathrm{mg} / \mathrm{g}), \mathrm{k}_{1}(\mathrm{~min})$ is the calculated pseudo-first-order rate constant, $\mathrm{k}_{2}$ is the calculated pseudo-second-order rate constant (g/mg.min), $\mathrm{K}_{\mathrm{id}}\left(\mathrm{mg} / \mathrm{g} \cdot \mathrm{min}^{1 / 2}\right)$ is the intraparticle diffusion rate constant, $\mathrm{C}_{\mathrm{i}}$ is the intercept which indicates the boundary layer thickness [43, 44].

Based on the parameters of these models are given in Table 4. The kinetic data obtained were tested based on the determination coefficient $\left(\mathrm{R}^{2}\right)$ and equilibrium adsorption capacity (qe). From Table 4 , it was noticed that $\mathrm{R}^{2}$ for the pseudo-second-order study was higher (close to unity) than that of pseudo-first-order and intraparticle diffusion models, the experimental $\mathrm{q}_{\mathrm{e}}$ values $\left(\mathrm{q}_{\mathrm{e}, \mathrm{exp}}\right)$ are in good agreement with the calculated $\mathrm{q}_{\mathrm{e}}$ value $\left(\mathrm{q}_{\mathrm{e}, \mathrm{cal}}\right)$ for the pseudo-secondorder model indicated a better fit than the pseudo-first-order model and intraparticle diffusion models. Further confirming chemisorptions of the Cr (VI) adsorption mechanism [45]. 
Table 4. Parameters of the kinetic models for hexavalent chromium adsorption by MAC.

\begin{tabular}{|c|c|c|c|c|c|c|c|c|c|c|}
\hline \multirow{2}{*}{$\begin{array}{l}\text { Concentration } \\
(\mathrm{mg} / \mathrm{L})\end{array}$} & \multirow[b]{2}{*}{$q_{\text {e,exp }}$} & \multicolumn{3}{|c|}{ Pseudo-first order } & \multicolumn{3}{|c|}{ Pseudo-second order } & \multicolumn{3}{|c|}{ Intraparticle diffusion } \\
\hline & & $\mathbf{q}_{\mathrm{e}, \mathrm{cal}}$ & $\mathbf{k}_{1}$ & $\mathbf{R}^{2}$ & $\mathbf{q}_{\mathrm{e}, \mathrm{cal}}$ & $\mathbf{k}_{2}$ & $\mathbf{R}^{2}$ & $\mathbf{k}_{\text {id }}$ & $\mathbf{C}$ & $\mathbf{R}^{2}$ \\
\hline 1 & 6.39 & 23.80 & 0.179 & 0.730 & 6.79 & 0.040 & 0.998 & 0.332 & 4.05 & 0.916 \\
\hline 2 & 13.78 & 18.68 & 0.113 & 0.731 & 14.74 & 0.015 & 0.998 & 0.808 & 7.97 & 0.965 \\
\hline 3 & 21.96 & 21.65 & 0.105 & 0.565 & 22.72 & 0.015 & 0.999 & 0.964 & 14.87 & 0.943 \\
\hline 4 & 28.86 & 35.71 & 0.110 & 0.596 & 32.26 & 0.008 & 0.998 & 1.426 & 18.37 & 0.966 \\
\hline 5 & 33.16 & 15.75 & 0.095 & 0.563 & 33.67 & 0.0194 & 0.999 & 0.781 & 27.29 & 0.943 \\
\hline
\end{tabular}

\subsection{Equilibrium study.}

An equilibrium study was investigated using the Langmuir, Freundlich, and Dubinin Radushkevich isotherms. The linearized forms of these models are expressed by the following equations [46-48]:

Langmuir isotherm: $\quad \frac{\mathrm{C}_{\mathrm{e}}}{\mathrm{q}_{\mathrm{e}}}=\frac{1}{\mathrm{q}_{\mathrm{m}} \mathrm{K}_{\mathrm{L}}}+\frac{1}{\mathrm{q}_{\mathrm{m}}} \mathrm{C}_{\mathrm{e}}$

Freundlich isotherm: $\quad \log \left(\mathrm{q}_{\mathrm{e}}\right)=\log \left(\mathrm{K}_{\mathrm{f}}\right)+\frac{1}{\mathrm{n}} \log \left(\mathrm{C}_{\mathrm{e}}\right)$

Dubinin-Radushkevich (D-R): $\quad \operatorname{Ln}\left(q_{e}\right)=\operatorname{Ln}\left(q_{m}\right)-B \varepsilon^{2}$

$$
\varepsilon=\operatorname{RTLn}\left(1+\frac{1}{c_{\mathrm{e}}}\right) \quad \text { and } \quad \mathrm{E}=\frac{1}{\sqrt{2 \mathrm{~B}}}
$$

Where $\mathrm{q}_{\mathrm{e}}$ is the equilibrium capacity at equilibrium, concentration $\mathrm{Ce}_{\mathrm{e}}, \mathrm{q}_{\mathrm{m}}$ is the Langmuir constant representing maximum monolayer adsorption capacity, and $\mathrm{K}_{\mathrm{L}}$ is the Langmuir constant related to adsorption's free energy, $\mathrm{K}_{\mathrm{f}}$ and $\mathrm{n}$ are constants affecting the adsorption capacity and intensity of adsorption, respectively. B is a constant that gives an idea about the mean free energy of adsorption per mole of the adsorbate, $\mathrm{q}_{\mathrm{m}}$ is the maximum adsorption capacity, and $\varepsilon$ is the polanyi potential.

The experimental isotherm parameters were conducted at four different temperatures $(298 \mathrm{~K}, 308 \mathrm{~K}, 318 \mathrm{~K}$, and $328 \mathrm{~K}$ ), and initial Cr (VI) concentrations of 1 to $6 \mathrm{mg} / \mathrm{L}$ with constant $\mathrm{pH}$ (1.5) are listed in Table 5.

Table 5. Isotherm constants for hexavalent chromium at different temperatures.

\begin{tabular}{l|c|c|c|c|c|c|c|c|c|c}
\multirow{2}{*}{ Temperature } & \multicolumn{4}{|c|}{ Langmuir } & \multicolumn{4}{c|}{ Freundlich } & \multicolumn{4}{c}{ Dubinin-Radushkevich } \\
\cline { 2 - 12 } & $\mathbf{q}_{\max }$ & $\mathbf{R}_{\mathbf{L}}$ & $\mathbf{R}^{\mathbf{2}}$ & $\mathbf{K}_{\mathbf{F}}$ & $\mathbf{1 / n}$ & $\mathbf{R}^{\mathbf{2}}$ & $\mathbf{q}_{\max }$ & $\mathbf{K}_{\mathbf{D}-\mathbf{R}}$ & $\mathbf{E}$ & $\mathbf{R}^{\mathbf{2}}$ \\
\hline $298 \mathrm{~K}$ & 34.12 & 0.067 & 0.998 & 32.72 & 0.497 & 0.972 & 31.34 & $3.10^{-8}$ & 4082 & 0.970 \\
\hline $308 \mathrm{~K}$ & 44.64 & 0.102 & 0.984 & 35.63 & 0.641 & 0.685 & 56.98 & $1.10^{-7}$ & 2236 & 0.895 \\
\hline $318 \mathrm{~K}$ & 56.17 & 0.127 & 0.999 & 48.87 & 0.684 & 0.988 & 38.54 & $3.10^{-8}$ & 4082 & 0.965 \\
\hline $328 \mathrm{~K}$ & 64.94 & 0.109 & 0.997 & 57.77 & 0.301 & 0.810 & 75.02 & $9.10^{-8}$ & 2357 & 0.998
\end{tabular}

Table 6. Comparison of adsorption capacities of $\mathrm{Cr}$ (VI) with other adsorbents.

\begin{tabular}{l|c|c|c} 
Adsorbents & $\mathbf{p H}$ & Qmax $(\mathbf{m g} / \mathbf{g})$ & References \\
\hline Activated carbon (F400) & 2 & 53.20 & {$[49]$} \\
\hline Tyres activated carbon & 2 & 58.50 & {$[49]$} \\
\hline Cactus leaves & 2 & 7.080 & {$[50]$} \\
\hline Eucalyptus bark & 2 & 45.00 & {$[51]$} \\
\hline Cone biomass of Thujaoriantalis & 1.5 & 49.00 & {$[52]$} \\
\hline Biogas residual slurry & 1.5 & 5.870 & {$[53]$} \\
\hline Maize cob & 1.5 & 13.80 & {$[55]$} \\
\hline Activated alumina & 1.5 & 25.57 & {$[55]$} \\
\hline Rice husk ash & 1.5 & 25.64 & This study
\end{tabular}

The table indicates that the maximum adsorbed capacity $\left(\mathrm{q}_{\max }\right)$ increases as the process temperature rises. These results demonstrate that adsorption on MAC is favorable by increasing the energy (endothermic process). The high $\mathrm{R}^{2}(0.997)$ and $\mathrm{qmax}$ values suggested that the Langmuir isotherm describes the adsorption process well compared to the Freundlich model 
and Dubinin-Radushkevich models at the different temperatures, respectively. The Langmuir isotherm model indicates the formation of monolayer surface adsorption of $\mathrm{Cr}$ (VI) ions on the specific homogeneous sites. Moreover, the monolayer adsorption capacity of MAC adsorbent was found to be $64.94 \mathrm{mg} / \mathrm{g}$ and was considerably high in comparison with the value of the other adsorbents of $\mathrm{Cr}(\mathrm{VI})$ removal reported in the literature (see Table 6).

The magnitude of $\mathrm{E}\left(\mathrm{kJ} \cdot \mathrm{mol}^{-1}\right)$ is used for estimating the type of adsorption mechanism. Suppose this value is between 8 and $16 \mathrm{~kJ} \cdot \mathrm{mol}-1$. In that case, the adsorption process is controlled by a chemical mechanism. In contrast, for E less than $8 \mathrm{~kJ} \cdot \mathrm{mol}^{-1}$, the adsorption process proceeds through a physical mechanism [56]. The calculated values of $\mathrm{E}$ (Table 5) suggested that $\mathrm{Cr}$ (VI) adsorption occurs via physical adsorption.

\subsection{Thermodynamics of the adsorption process.}

To observe the influence of temperature at different $\mathrm{Cr}$ (VI) concentration and to determine the spontaneity, stability, and thermal behavior of the process $\mathrm{Cr}$ (VI) adsorption, the change in free energy $\left(\Delta \mathrm{G}^{0}\right)$, enthalpy $\left(\Delta \mathrm{H}^{0}\right)$, and entropy $\left(\Delta \mathrm{S}^{0}\right)$ were estimated using following equations.

$$
\begin{gathered}
\Delta \mathrm{G}^{\circ}=\Delta \mathrm{H}^{\circ}-\mathrm{T} \Delta \mathrm{S}^{\circ} \\
\operatorname{Ln} \mathrm{K}_{\mathrm{C}}=\frac{\Delta \mathrm{S}^{\circ}}{\mathrm{R}}-\frac{\Delta \mathrm{H}^{\circ}}{\mathrm{RT}}
\end{gathered}
$$

Where ' $\mathrm{T}$ ' is the solution temperature $(\mathrm{K})$ and $\mathrm{R}$ is the universal gas constant $(8.314 \mathrm{~J} / \mathrm{mol} . \mathrm{K})$ and $K_{d}$ is the coefficient of distribution given by [56]:

$$
\mathrm{K}_{\mathrm{d}}=\frac{\mathrm{q}_{\mathrm{e}}}{\mathrm{c}_{\mathrm{e}}}
$$

The thermodynamic results calculated for the $\mathrm{Cr}(\mathrm{VI})$ adsorption are presented in Table 7. The negative values of $\Delta G^{0}$ suggest the adsorption process is thermodynamically feasible and spontaneous. At the same time, the positive value of $\Delta \mathrm{S}^{0}$ demonstrates the increased randomness at the solution interface during $\mathrm{Cr}$ (VI) adsorption. The positive value of $\Delta \mathrm{H}^{0}$ for this study confirms that the interaction between $\mathrm{Cr}(\mathrm{VI})$ ion and MAC adsorbent surface is endothermic.

\begin{tabular}{|c|c|c|c|c|c|c|}
\hline \multirow{2}{*}{$\begin{array}{l}\text { Concentration } \\
(\mathrm{mg} / \mathrm{L})\end{array}$} & \multicolumn{4}{|c|}{$\Delta G^{0}(\mathrm{~kJ} / \mathrm{mol})$} & \multirow[t]{2}{*}{$\Delta \mathbf{H}^{0}(\mathrm{~kJ} / \mathrm{mol})$} & \multirow[t]{2}{*}{$\Delta S^{0}(J / k ~ m o l)$} \\
\hline & 298 k & $308 \mathrm{k}$ & $318 \mathrm{k}$ & $328 \mathrm{k}$ & & \\
\hline 1 & -7.942 & -9.186 & -10.43 & -11.67 & 29.129 & 124.4 \\
\hline 2 & -8.983 & -10.99 & -12.99 & -15.01 & 50.855 & 200.8 \\
\hline 3 & -9.016 & -9.863 & -10.71 & -11.55 & 16.209 & 84.65 \\
\hline 4 & -9.412 & -10.64 & -11.86 & -13.09 & 27.152 & 122.7 \\
\hline 5 & -10.18 & -10.66 & -11.15 & -11.63 & 4.206 & 48.29 \\
\hline
\end{tabular}

Table 7. Thermodynamic parameters for the adsorption study at various $\mathrm{Cr}$ (VI) concentrations using MAC adsorbent.

\section{Conclusions}

As a result of this study, the full factorial experimental design was applied to optimize the hexavalent chromium $\mathrm{Cr}$ (VI) removal efficiency by MAC and to determine the main and interactive effects of four various factors like $\mathrm{pH}, \mathrm{Cr}$ (VI) concentration, adsorbent dosage and contact time on the adsorption of $\mathrm{Cr}$ (VI) by the medlar activated carbon. The main conclusions that can be drawn from this work are given below, Main effects like $\mathrm{pH}$ (A), adsorbent dose 
(C), and contact time (D) were significant, and the interaction effect between $\mathrm{pH}$ Concentration $(\mathrm{AB}), \mathrm{pH}$ adsorbent dose (AC), $\mathrm{pH}$ contact time (AD) and $\mathrm{pH}$ concentration adsorbent dose $(\mathrm{ABC})$ was the most influencing interaction. The kinetics study was followed by the pseudosecond-order kinetic model, whereas equilibrium isotherm data were best interpreted by the Langmuir isotherm model with a high maximum adsorption capacity of $64.94 \mathrm{mg} / \mathrm{g}$ and high correlation coefficient $\left(\mathrm{R}^{2}=0.997\right)$. Thermodynamic parameters indicate that adsorption of $\mathrm{Cr}$ (VI) was exothermic, spontaneous, and physisorption process.

\section{Funding}

This research received no external funding.

\section{Acknowledgments}

The authors are grateful who have participated in this research work.

\section{Conflicts of Interest}

The authors declare no conflict of interest.

\section{References}

1. Altundogan, H.S. Cr(VI) removal from aqueous solution by iron (III) hydroxide-loaded sugar beet pulp. Process Biochemistry 2005, 40, 1443-1452, https://doi.org/10.1016/j.procbio.2004.06.027.

2. Pessôa de França, F.; Mora Tavares, A.P.; Augusto da Costa, A.C. Calcium interference with continuous biosorption of zinc by Sargassum sp. (Phaeophyceae) in tubular laboratory reactors. Bioresource Technology 2002, 83, 159-163, https://doi.org/10.1016/S0960-8524(01)00198-5.

3. Vegliò, F.; Esposito, A.; Reverberi, A.P. Standardisation of heavy metal biosorption tests: equilibrium and modelling study. Process Biochemistry 2003, 38, 953-961, https://doi.org/10.1016/S0032-9592(02)002352 .

4. El-Sikaily, A.; Nemr, A.E.; Khaled, A.; Abdelwehab, O. Removal of toxic chromium from wastewater using green alga Ulva lactuca and its activated carbon. Journal of Hazardous Materials 2007, 148, 216-228, https://doi.org/10.1016/j.jhazmat.2007.01.146.

5. Li, H.; Li, Z.; Liu, T.; Xiao, X.; Peng, Z.; Deng, L. A novel technology for biosorption and recovery hexavalent chromium in wastewater by bio-functional magnetic beads. Bioresource Technology 2008, 99, 6271-6279, https://doi.org/10.1016/j.biortech.2007.12.002.

6. Hutton, G.; Haller, L.; Water, S.. World Health Organization. Evaluation of the costs and benefits of water and sanitation improvements at the global level (No. WHO/SDE/WSH/04.04). World Health Organization. 2004.

7. Adane, T.; Dessie, A. Adaptability of Teff husk activated carbon for removal of hexavalent chromium from tannery wastewater at optimized process condition. Applied Water Science 2020, 10, 1-7, https://doi.org/10.1007/s13201-020-01269-1.

8. Su, M.; Fang, Y.; Li, B.; Yin, W.; Gu, J.; Liang, H.; Li, P.; Wu, J. Enhanced hexavalent chromium removal by activated carbon modified with micro-sized goethite using a facile impregnation method. Science of The Total Environment 2019, 647, 47-56, https://doi.org/10.1016/j.scitotenv.2018.07.372.

9. Orbak, Â.Y.; Orbak, İ. Effective Factor Analysis for chromium(VI) removal from aqueous solutions and its application to tunçbilek lignite using design of experiments. Journal of Chemistry 2019, 2019, https://doi.org/10.1155/2019/1263735.

10. Yang, Z.-h.; Wang, B.; Chai, L.-y.; Wang, Y.-y.; Wang, H.-y.; Su, C.-q. Removal of Cr(III) and Cr(VI) from aqueous solution by adsorption on sugarcane pulp residue. Journal of Central South University of Technology 2009, 16, 101-107, https://doi.org/10.1007/s11771-009-0017-3.

11. Hamadi, N.K.; Chen, X.D.; Farid, M.M.; Lu, M.G.Q. Adsorption kinetics for the removal of chromium(VI) from aqueous solution by adsorbents derived from used tyres and sawdust. Chemical Engineering Journal 2001, 84, 95-105, https://doi.org/10.1016/S1385-8947(01)00194-2.

12. Bhattacharya, A.K.; Naiya, T.K.; Mandal, S.N.; Das, S.K. Adsorption, kinetics and equilibrium studies on removal of $\mathrm{Cr}(\mathrm{VI})$ from aqueous solutions using different low-cost adsorbents. Chemical Engineering Journal 2008, 137, 529-541, https://doi.org/10.1016/j.cej.2007.05.021. 
13. Aggarwal, D.; Goyal, M.; Bansal, R.C. Adsorption of chromium by activated carbon from aqueous solution. Carbon 1999, 37, 1989-1997, https://doi.org/10.1016/S0008-6223(99)00072-X.

14. Annadurai, G.; Juang, R.-S.; Lee, D.-J. Factorial design analysis for adsorption of dye on activated carbon beads incorporated with calcium alginate. Advances in Environmental Research 2002, 6, 191-198, https://doi.org/10.1016/S1093-0191(01)00050-8.

15. Ravikumar, K.; Deebika, B.; Balu, K. Decolourization of aqueous dye solutions by a novel adsorbent: Application of statistical designs and surface plots for the optimization and regression analysis. Journal of Hazardous Materials 2005, 122, 75-83, https://doi.org/10.1016/j.jhazmat.2005.03.008.

16. El Kassimi, A.; Achour, Y.; El Himri, M.; Laamari, M.R.; El Haddad, M. Optimization of preparation conditions of highly efficient activated carbon for use in water treatment - experimental design approach. International Journal of Environmental Analytical Chemistry 2021, 1-23, https://doi.org/10.1080/03067319.2020.1861261.

17. El Kassimi, A.; Achour, Y.; El Himri, M.; Laamari, M. R.; El Haddad, M. Process optimization of high surface area activated carbon prepared from cucumis melo by $\mathrm{H}_{3} \mathrm{PO}_{4}$ activation for the removal of cationic and anionic dyes using full factorial design. Biointerface Research in Applied Chemistry 2021, 11, 126212679, https://doi.org/10.33263/BRIAC115.1266212679.

18. Regti, A.; El Kassimi, A.; Laamari, M.R.; El Haddad, M. Competitive adsorption and optimization of binary mixture of textile dyes: A factorial design analysis. J. Assoc. Arab Univ. Basic Appl. Sci. 2017, 24, 1-9, https://doi.org/10.1016/j.jaubas.2016.07.005.

19. Regti, A.; Laamari, M.R.; Stiriba, S.-E.; El Haddad, M. Use of response factorial design for process optimization of basic dye adsorption onto activated carbon derived from Persea species. Microchemical Journal 2017, 130, 129-136, https://doi.org/10.1016/j.microc.2016.08.012.

20. Rachel, N.; Bacaoui, A.; Daouda, K.; Nsami, N.; Gaelle, D.; Yaacoubi, A.; Louarrat, M.; Joseph, K. Optimization study of the removal of atrazine from aqueous solution on to composite activated carbon-silver using response surface methodology. Materials Sciences and Applications 2017, 08, 258-272, https://doi.org/10.4236/msa.2017.83018.

21. Garba, Z.N.; Abdul Rahim, A.; Hamza, S.A. Potential of Borassus aethiopum shells as precursor for activated carbon preparation by physico-chemical activation; optimization, equilibrium and kinetic studies. Journal of Environmental Chemical Engineering 2014, 2, 1423-1433, https://doi.org/10.1016/j.jece.2014.07.010.

22. Oyekanmi, A.A.; Ahmad, A.; Hossain, K.; Rafatullah, M. Adsorption of Rhodamine B dye from aqueous solution onto acid treated banana peel: Response surface methodology, kinetics and isotherm studies. PLOS ONE 2019, 14, https://doi.org/10.1371/journal.pone.0216878.

23. Shi, Q.; Zhang, J.; Zhang, C.; Li, C.; Zhang, B.; Hu, W.; Xu, J.; Zhao, R. Preparation of activated carbon from cattail and its application for dyes removal. Journal of Environmental Sciences 2010, 22, 91-97, https://doi.org/10.1016/S1001-0742(09)60079-6.

24. Yu, J.C.; Ho, W.; Yu, J.; Yip, H.; Wong, P.K.; Zhao, J. Efficient visible-light-induced photocatalytic disinfection on sulfur-doped nanocrystalline titania. Environmental Science \& Technology 2005, 39, 11751179, https://doi.org/10.1021/es035374h.

25. Saka, C.; Elçi Ölçenoğlu, G.; Şahin, Ö. Oxygen plasma treated petroleum coke adsorbent: characterization, synthesis, mechanism, and application for enhancement of malachite green removal. International Journal of Environmental Analytical Chemistry 2021, 1-17, https://doi.org/10.1080/03067319.2021.1873305.

26. Pourabadeh, A.; Baharinikoo, L.; Nouri, A.; Mehdizadeh, B.; Shojaei, S. The optimisation of operating parameters of dye removal: application of designs of experiments. Int. J. Environ. Anal. Chem. 2019, 1-10, https://doi.org/10.1080/03067319.2019.1680657.

27. Behera, S.K.; Sahni, S.; Tiwari, G.; Rai, A.; Mahanty, B.; Vinati, A.; Rene, E.R.; Pugazhendhi, A. Removal of chromium from synthetic wastewater using modified maghemite nanoparticles. Applied Sciences 2020, 10, https://doi.org/10.3390/app10093181.

28. Parsaeian, M.R.; Dadfarnia, S.; Haji Shabani, A.M.; Hafezi Moghaddam, R. Green synthesis of a high capacity magnetic polymer nanocomposite sorbent based on the natural products for removal of Reactive Black 5. International Journal of Environmental Analytical Chemistry 2020, 1-15, https://doi.org/10.1080/03067319.2020.1748612.

29. Mazaheri, H.; Ghaedi, M.; Asfaram, A.; Hajati, S. Performance of CuS nanoparticle loaded on activated carbon in the adsorption of methylene blue and bromophenol blue dyes in binary aqueous solutions: Using ultrasound power and optimization by central composite design. Journal of Molecular Liquids 2016, 219, 667-676, https://doi.org/10.1016/j.molliq.2016.03.050.

30. Ghaedi, M.; Rozkhoosh, Z.; Asfaram, A.; Mirtamizdoust, B.; Mahmoudi, Z.; Bazrafshan, A.A. Comparative studies on removal of Erythrosine using $\mathrm{ZnS}$ and $\mathrm{AgOH}$ nanoparticles loaded on activated carbon as adsorbents: Kinetic and isotherm studies of adsorption. Spectrochimica Acta Part A: Molecular and Biomolecular Spectroscopy 2015, 138, 176-186, https://doi.org/10.1016/j.saa.2014.10.046.

31. Ghaedi, M.; Rozkhoosh, Z.; Asfaram, A.; Mirtamizdoust, B.; Mahmoudi, Z.; Bazrafshan, A.A. Comparative studies on removal of Erythrosine using $\mathrm{ZnS}$ and $\mathrm{AgOH}$ nanoparticles loaded on activated carbon as 
adsorbents: Kinetic and isotherm studies of adsorption. Spectrochimica Acta Part A: Molecular and Biomolecular Spectroscopy 2015, 138, 176-186, https://doi.org/10.1016/j.saa.2014.10.046.

32. Dehghani, M.H.; Sanaei, D.; Ali, I.; Bhatnagar, A. Removal of chromium(VI) from aqueous solution using treated waste newspaper as a low-cost adsorbent: Kinetic modeling and isotherm studies. Journal of Molecular Liquids 2016, 215, 671-679, https://doi.org/10.1016/j.molliq.2015.12.057.

33. Mondal, N.K.; Basu, S.; Das, B. Decontamination and optimization study of hexavalent chromium on modified chicken feather using response surface methodology. Applied Water Science 2019, 9, 1-15, https://doi.org/10.1007/s13201-019-0930-z.

34. Saha, R.; Mukherjee, K.; Saha, I.; Ghosh, A.; Ghosh, S.K.; Saha, B. Removal of hexavalent chromium from water by adsorption on mosambi (Citrus limetta) peel. Research on Chemical Intermediates 2013, 39, 22452257, https://doi.org/10.1007/s11164-012-0754-z.

35. Gottipati, R.; Mishra, S. Process optimization of adsorption of Cr(VI) on activated carbons prepared from plant precursors by a two-level full factorial design. Chemical Engineering Journal 2010, 160, 99-107, https://doi.org/10.1016/j.cej.2010.03.015.

36. Bingol, D.; Tekin, N.; Alkan, M. Brilliant Yellow dye adsorption onto sepiolite using a full factorial design. Applied Clay Science 2010, 50, 315-321, https://doi.org/10.1016/j.clay.2010.08.015.

37. Masip Macía, Y.; Pedrera, J.; Castro, M.T.; Vilalta, G. Analysis of Energy Sustainability in Ore Slurry Pumping Transport Systems. Sustainability 2019, 11, https://doi.org/10.3390/su11113191.

38. Safa, Y.; Bhatti, H.N. Biosorption of Direct Red-31 and Direct Orange-26 dyes by rice husk: Application of factorial design analysis. Chemical Engineering Research and Design 2011, 89, 2566-2574, https://doi.org/10.1016/j.cherd.2011.06.003.

39. Hassani, A.; Alidokht, L.; Khataee, A.R.; Karaca, S. Optimization of comparative removal of two structurally different basic dyes using coal as a low-cost and available adsorbent. Journal of the Taiwan Institute of Chemical Engineers 2014, 45, 1597-1607, https://doi.org/10.1016/j.jtice.2013.10.014.

40. Aziz, E.K.; Abdelmajid, R.; Rachid, L.M.; Mohammadine, E.H. Adsorptive removal of anionic dye from aqueous solutions using powdered and calcined vegetables wastes as low-cost adsorbent. Arab Journal of Basic and Applied Sciences 2018, 25, 93-102, https://doi.org/10.1080/25765299.2018.1517861.

41. Abd-Elhamid, A.I.; Emran, M.; El-Sadek, M.H.; El-Shanshory, A.A.; Soliman, H.M.A.; Akl, M.A.; Rashad, M. Enhanced removal of cationic dye by eco-friendly activated biochar derived from rice straw. Applied Water Science 2020, 10, 1-11, https://doi.org/10.1007/s13201-019-1128-0.

42. Harrou, A.; Gharibi, E.; Nasri, H.; El Ouahabi, M. Thermodynamics and kinetics of the removal of methylene blue from aqueous solution by raw kaolin. SN Applied Science 2020, 2, 1-11, https://doi.org/10.1007/s42452020-2067-y.

43. El Kassimi, A.; Achour, Y.; El Himri, M.; Laamari, R.; El Haddad, M. High efficiency of natural safiot clay to remove industrial dyes from aqueous media: Kinetic, isotherm adsorption and thermodynamic studies. Biointerface Research in Applied Chemistry 2021, 11, 12717-12731, https://doi.org/10.33263/BRIAC115.1271712731.

44. El Kassimi, A.; Regti, A.; Laamari, R.; El Haddad, M. Assessment and enhancement of powdered and activated carbon derived from persea nuts for adsorptive removal dyes from wastewaters. Der Pharma Chem. 2017, 9, 38-45,

45. Suteu, D.; Zaharia, C.; Malutan, T. Equilibrium, kinetic, and thermodynamic studies of Basic Blue 9 dye sorption on agro-industrial lignocellulosic materials. Open Chemistry 2012, 10, 1913-1926, https://doi.org/10.2478/s11532-012-0122-2.

46. El Kassimi, A.; Boutouil, A.; El Himri, M.; Rachid Laamari, M.; El Haddad, M. Selective and competitive removal of three basic dyes from single, binary and ternary systems in aqueous solutions: A combined experimental and theoretical study. Journal of Saudi Chemical Society 2020, 24, 527-544, https://doi.org/10.1016/j.jscs.2020.05.005.

47. Romdhane, D.F.; Satlaoui, Y.; Nasraoui, R.; Charef, A.; Azouzi, R. Adsorption, modeling, thermodynamic, and kinetic studies of methyl red removal from textile-polluted water using natural and purified organic matter rich clays as low-cost adsorbent. Journal of Chemistry 2020, 2020, https://doi.org/10.1155/2020/4376173.

48. Nadir, I.; Achour, Y.; El Kassimi, A.; El Himri, M.; Laamari, M.R.; El Haddad, M. Removal of antibiotic sulfamethazine from aqueous media. Physical Chemistry Research 2021, 9, 165-180, https://doi.org/10.22036/pcr.2020.249992.1839.

49. Kobya, M. Adsorption, kinetic and equilibrium studies of $\mathrm{Cr}(\mathrm{VI})$ by hazelnut shell activated carbon. Adsorption Science \& Technology 2004, 22, 51-64, https://doi.org/10.1260/026361704323150999.

50. Mauseth, J.D. Structure-function relationships in highly modified shoots of Cactaceae. Ann. Bot. 2006, 98, 901-926, https://doi.org/10.1093/aob/mcl133.

51. Sarin, V.; Pant, K.K. Removal of chromium from industrial waste by using eucalyptus bark. Bioresource Technology 2006, 97, 15-20, https://doi.org/10.1016/j.biortech.2005.02.010. 
52. Oguz, E. Adsorption characteristics and the kinetics of the $\mathrm{Cr}(\mathrm{VI})$ on the Thuja oriantalis. Colloids and Surfaces A: Physicochemical and Engineering Aspects 2005, 252, 121-128, https://doi.org/10.1016/j.colsurfa.2004.10.004.

53. Namasivayam, C.; Yamuna, R.T. Adsorption of chromium (VI) by a low-cost adsorbent: Biogas residual slurry. Chemosphere 1995, 30, 561-578, https://doi.org/10.1016/0045-6535(94)00418-T.

54. Sharma, D.C.; Forster, C.F. A preliminary examination into the adsorption of hexavalent chromium using low-cost adsorbents. Bioresource Technology 1994, 47, 257-264, https://doi.org/10.1016/09608524(94)90189-9.

55. Bhattacharya, A.K.; Naiya, T.K.; Mandal, S.N.; Das, S.K. Adsorption, kinetics and equilibrium studies on removal of $\mathrm{Cr}(\mathrm{VI})$ from aqueous solutions using different low-cost adsorbents. Chemical Engineering Journal 2008, 137, 529-541, https://doi.org/10.1016/j.cej.2007.05.021.

56. Regti, A.; El Kassimi, A.; Laamari, M.R.; El Haddad, M. Competitive adsorption and optimization of binary mixture of textile dyes: A factorial design analysis. J. Assoc. Arab Univ. Basic Appl. Sci. 2017, 24, 1-9, https://doi.org/10.1016/j.jaubas.2016.07.005. 